\title{
Factors associated with milk processing characteristics predicted by mid-infrared spectroscopy in a large database of dairy cows
}

\author{
G. Visentin, ${ }^{\star} \dagger$ M. De Marchi, ${ }^{*}$ D. P. Berry, $\dagger$ A. McDermott, ${ }^{*} \dagger$ M. A. Fenelon, $\ddagger$ M. Penasa, ${ }^{*}$ and S. McParland $\dagger^{1}$ \\ *Department of Agronomy, Food, Natural Resources, Animals and Environment (DAFNAE), University of Padova, Viale dell'Università 16, \\ 35020 Legnaro (PD), Italy \\ †Animal and Grassland Research and Innovation Center, Teagasc, Moorepark, Fermoy, Co. Cork, Ireland \\ $\ddagger$ Teagasc Food Research Center, Moorepark, Fermoy, Co. Cork, Ireland
}

\begin{abstract}
Despite milk processing characteristics being important quality traits, little is known about the factors underlying their variability, due primarily to the resources required to measure these characteristics in a sufficiently large population. Cow milk coagulation properties (rennet coagulation time, curd-firming time, curd firmness 30 and 60 min after rennet addition), heat coagulation time, casein micelle size, and $\mathrm{pH}$ were generated from available mid-infrared spectroscopy prediction models. The prediction models were applied to 136,807 spectra collected from 9,824 Irish dairy cows from research and commercial herds. Sources of variation were investigated using linear mixed models that included the fixed effects of calendar month of test; milking time in the day; linear regressions on the proportion of Friesian, Jersey, Montbéliarde, Norwegian Red, and "other" breeds in the cow; coefficients of heterosis and of recombination loss; parity; stage of lactation; and the 2 -way interaction parity $\times$ stage of lactation. Withinand across-parity cow effects, contemporary group, and a residual term were also included as random effects in the model. Supplementary analyses considered the inclusion of either test-day milk yield or milk protein concentration as fixed-effects covariates in the multiple regression models. Milk coagulation properties were most favorable (i.e., short rennet coagulation time and strong curd firmness) for cheese manufacturing in early lactation, concurrent with the lowest values of both $\mathrm{pH}$ and casein micelle size. Milk coagulation properties and $\mathrm{pH}$ deteriorated in mid lactation but improved toward the end of lactation. In direct contrast, heat coagulation time was more favorable in mid lactation and less suitable (i.e., shorter) for high temperature treatments in both early and late lactation. Relative to multipa-
\end{abstract}

Received September 21, 2016.

Accepted December 9, 2016.

${ }^{1}$ Corresponding author: sinead.mcparland@teagasc.ie rous cows, primiparous cows, on average, yielded milk with shorter rennet coagulation time and longer heat coagulation time. Milk from the evening milking session had shorter rennet coagulation time and greater curd firmness, as well as lower heat coagulation time and lower $\mathrm{pH}$ compared with milk from the morning session. Jersey cows, on average, yielded milk more suitable for cheese production rather than for milk powder production. When protein concentration was included in the model, the improvement of milk coagulation properties toward the end of lactation was no longer apparent. Results from the present study may aid in decisionmaking for milk manufacturing, especially in countries characterized by a seasonal supply of fresh milk.

Key words: milk processability, seasonal variation, milk quality, lactation

\section{INTRODUCTION}

Milk processing characteristics are indicators of both the potential and ease of transforming raw milk into dairy products, including value-added products (i.e., cheese and butter) as well as products with extended shelf life (UHT milk and milk powder). Several quality traits contribute to milk processing characteristics, such as rennet coagulation time (RCT), curd-firming time $\left(\mathbf{k}_{\mathbf{2 0}}\right)$, curd firmness 30 or 60 min after addition of rennet to milk ( $\mathbf{a}_{30}$ and $\mathbf{a}_{60}$, respectively), heat coagulation time (HCT), casein micelle size (CMS), and $\mathrm{pH}$. Rennet coagulation time, $\mathrm{k}_{20}, \mathrm{a}_{30}$, and $\mathrm{a}_{60}$ are generally referred to as milk coagulation properties. Short to medium milk rennet reactivity and greater curd firming capacity are desirable attributes for cheese-making and associated with greater cheese yield (Aleandri et al., 1989; Formaggioni et al., 2008; Pretto et al., 2013). Heat coagulation time, which depicts milk protein stability when subjected to heat treatment, has a fundamental role in extending milk shelf life (Sikand et al., 2010). Smaller casein micelles are preferable when transforming milk into cheese (Glantz et al., 2010) and milk powder (Chen et al., 2014), and lower pH is gener- 
ally desired for processing milk into cheese (Pretto et al., 2013) but not into milk powder (Singh, 2004).

Within- and across-lactation variability among dairy cows has been documented for both milk coagulation properties and $\mathrm{pH}$ (Ikonen et al., 2004; Vallas et al., 2010; Penasa et al., 2014). Milk coagulation properties and $\mathrm{pH}$ tend to be least favorable for cheese-making in mid lactation (Ikonen et al., 2004; Vallas et al., 2010), and milk coagulation properties and $\mathrm{pH}$ deteriorate with cow parity (Penasa et al., 2014). Breed differences for milk coagulation properties have been documented in dairy cows (De Marchi et al., 2007; Poulsen et al., 2013). Both De Marchi et al. (2007) and Poulsen et al. (2013) reported that milk produced from higher-yielding dairy breeds had, on average, reduced coagulation ability. Few studies have quantified the associations between dairy cow breed and HCT (McLean et al., 1987; Barłowska et al., 2014) and CMS (Devold et al., 2000; Auldist et al., 2002), and these studies have generally been limited in population size. Because of the high resource requirements to accurately quantify milk processing characteristics, only a few studies (Ikonen et al., 2004; Vallas et al., 2010; Poulsen et al., 2013), which have generally been limited to milk coagulation properties, have attempted to identify factors contributing to the variability in milk coagulation properties using a large population of cows. Contributing factors to variability in milk coagulating characteristics were investigated in 4,664 Finnish Ayrshire dairy cows (Ikonen et al., 2004), in 4,191 primiparous Estonian Holstein (Vallas et al., 2010), and in 456 Danish Holstein, 436 Danish Jersey, and 407 Swedish Red lactating cows (Poulsen et al., 2013).

The objective of the present study was to identify the factors associated with a range of milk processing characteristics, predicted by mid-infrared spectroscopy analysis, in a large database of seasonal calving, grassbased dairy cows. Factors identified in the present study will be useful in a decision support tool for the dairy industry to predict and manage their product portfolio influenced by milk processability.

\section{MATERIALS AND METHODS}

\section{Data}

A total of 174,062 milk samples spectra collected between January 2013 and December 2015 from 10,394 dairy cows in 76 Irish herds were available. Of the 76 farms, 7 were research farms operated by Teagasc Animal and Grassland Research and Innovation Center (Moorepark, Fermoy, Co. Cork, Ireland). Cows ( $\mathrm{n}=$ $1,661)$ in these research herds participated in various experimental treatments based on the evaluation of different sward varieties and feeding strategies, different stocking rates, different calving periods, and different lengths of grazing period. A total of 2,956 lactation records were available from these cows. Almost all the animals were fed a basal diet of grazed pasture and were sporadically supplemented with a small quantity of concentrates as per the experimental treatment. Animals were milked twice a day, at $0700 \mathrm{~h}$ (a.m.) and 1500 h (p.m.), and milk yield was recorded at each milking. Individual milk samples were taken separately, once weekly, on consecutive p.m. and a.m. milkings. On average, 78 milk samples per cow were available from the research herds.

The remaining 69 herds in the data set were commercial herds operating in southwest Ireland. Animals ( $\mathrm{n}=8,733)$ were milked twice a day, and a composite individual cow a.m. + p.m. milk sample was collected (approximately 1,249 samples per month) and sent for mid-infrared spectroscopy analysis as part of an ongoing research study. Milk yield of the commercial herds represented the entire daily yield obtained from the day of milk testing. The average number of collected milk samples per cow was 5.15 , and a total of 14,873 lactation records were available.

Samples were collected from cows generally calving between January and April, inclusive; however, a small proportion $(1.81 \%)$ of samples originated from a research farm where calving between September and November, inclusive, was adopted. Milk samples from all 76 herds were kept at refrigerating temperature and analyzed within a week of collection using the same MilkoScan FT6000 (Foss Electronic A/S, Hillerød, Denmark) in the laboratory of Teagasc Animal and Grassland Research and Innovation Center. Milk chemical composition (concentration of protein, casein, fat, lactose, total solids, and urea) was derived for all milk samples, and SCC was determined using a Fossomatic (Foss Electronic A/S). Moreover, for each milk sample, spectral information containing 1,060 mid-infrared transmittance data in the region between 900 and 5,000 $\mathrm{cm}^{-1}$ was captured and stored.

\section{Development of Prediction Models for Milk Technological Traits}

Details of the selection of milk samples, measurement of the reference values, and the development of the prediction equations for the milk processing characteristics are described by Visentin et al. (2015). Briefly, during 2013 and 2014, a calibration data set was generated using individual bovine milk samples collected from the 7 Irish research herds also contributing to the data 
in the present study. Milk coagulation properties were determined on 560 samples using a Formagraph (Foss Electronic A/S). The output of the Formagraph is a graph of curd firmness against time, where RCT represents the time required to induce milk coagulation after rennet addition, $\mathrm{k}_{20}$ is the time between the gel development and the achievement of a width of $20 \mathrm{~mm}$ in the graph, and $\mathrm{a}_{30}$ and $\mathrm{a}_{60}$ are the widths of the graph after 30 and $60 \mathrm{~min}$ from rennet addition, respectively.

Milk HCT was measured on 509 samples using a hot oil bath (Elbanton BV, Kerkdriel, the Netherlands), by setting the temperature to $140^{\circ} \mathrm{C}$ at an oscillating speed of $8 \mathrm{rpm}$. Heat coagulation time was recorded when, at visual inspection, milk started to flocculate.

Casein micelle size, which represents the average diameter of casein micelles of a milk sample, was measured on 688 samples using a Zetasizer Nano system (Malvern Instruments Inc., Worcester, UK). The measurement was carried out at $25^{\circ} \mathrm{C}$ using the noninvasive backscatter optics at $173^{\circ}$. Milk pH was recorded on 708 samples with a SevenCompact pH meter S220 (Mettler Toledo AG, Greifensee, Switzerland).

Prediction models were developed for each trait separately using partial least squares regression (PROC PLS, SAS Institute Inc., Cary, NC) as detailed by Visentin et al. (2015). The accuracy of the prediction models is summarized in Table 1 .

Table 1. Number of test-day records (n) and least squares means (LSM) of milk yield, predicted milk composition, SCS, and predicted milk technological traits ${ }^{1}$ for the reference animal ${ }^{2}$

\begin{tabular}{lrrrr}
\hline Trait $^{3}$ & $\mathrm{n}$ & $\mathrm{LSM}$ & $\mathrm{R}_{\mathrm{C}}^{2}$ & $\mathrm{SEP}_{\mathrm{C}}$ \\
\hline Milk, kg & 134,155 & 15.92 & & \\
Protein, \% & 128,561 & 3.61 & & \\
Casein, \% & 128,615 & 2.71 & & \\
Fat, \% & 128,647 & 3.90 & & \\
Lactose, \% & 128,510 & 4.70 & & \\
Total solids, \% & 128,747 & 12.87 & & \\
Urea, mg/dL & 127,996 & 30.06 & & \\
SCS, units & 76,595 & 1.69 & & \\
RCT, min & 136,102 & 21.84 & 0.61 & 5.64 \\
$\mathrm{k}_{20}$, min & 136,340 & 5.94 & 0.59 & 1.47 \\
$\mathrm{a}_{30}, \mathrm{~mm}$ & 126,799 & 27.42 & 0.50 & 11.32 \\
$\mathrm{a}_{60}, \mathrm{~mm}$ & 135,605 & 32.10 & 0.26 & 10.33 \\
HCT, min & 134,185 & 6.80 & 0.55 & 1.58 \\
CMS, nm & 136,165 & 170.54 & 0.23 & 28.11 \\
pH & 136,126 & 6.71 & 0.73 & 0.06 \\
\hline
\end{tabular}

${ }^{1}$ The accuracy of the prediction models is from Visentin et al. (2015); $\mathrm{R}_{\mathrm{C}}^{2}=$ coefficient of determination in cross validation; $\mathrm{SEP}_{\mathrm{C}}=$ standard error of prediction in cross validation.

${ }^{2}$ Third-parity cow, $100 \%$ Holstein, milked in the morning, averaged across all classes of stage of lactation and all calendar months of test. ${ }^{3} \mathrm{SCS}=\log _{10}(\mathrm{SCC}) ; \mathrm{RCT}=$ rennet coagulation time; $\mathrm{k}_{20}=$ curd-firming time; $\mathrm{a}_{30}=$ curd firmness 30 min after rennet addition to milk; $\mathrm{a}_{60}$ $=$ curd firmness $60 \mathrm{~min}$ after rennet addition to milk; HCT $=$ heat coagulation time; CMS = casein micelle size.

\section{Generation of Predictions from Spectral Data}

For all 174,062 milk samples collected in the present study, spectral data were transformed from transmittance to absorbance values by taking the logarithm to the base 10 of the reciprocal of the transmittance value. Two spectral wavelength regions $\left(1,580-1,710 \mathrm{~cm}^{-1}\right.$ and 2,990-3,690 $\mathrm{cm}^{-1}$ ), characterized by low signal-to-noise ratio and associated with water absorption (Hewavitharana and Brakel, 1997), were discarded before statistical analysis. Subsequently, principal component analysis (PROC PRINCOMP, SAS Institute Inc.) was undertaken on the milk spectra to detect outliers.

To identify only the spectra similar to those used to develop the prediction models, the Mahalanobis distance from the centroid (i.e., the mean of first, second, third, and fourth principal components) of the cluster of samples included in the calibration data set was calculated as the sum of squares of the centered and scaled scores of the first 4 principal components (Brereton, 2015). Outlier spectra from the entire data set were subsequently defined as samples with a Mahalanobis distance from the centroid of the calibration data set $>97.5 \%$ percentile of a $\chi^{2}$ distribution with $p$ degrees of freedom. Following the removal of outliers, 157,192 spectra (i.e., $90 \%$ of the initial data set) from 10,112 dairy cows were retained (Supplemental Figures S1 and S2; http://doi.org/10.3168/jds.2016-12028). The prediction models were applied to these spectra to predict RCT, $\mathrm{k}_{20}, \mathrm{a}_{30}, \mathrm{a}_{60}, \mathrm{HCT}, \mathrm{CMS}$, and $\mathrm{pH}$.

\section{Data Editing}

Obvious data errors for predicted RCT, $\mathrm{k}_{20}, \mathrm{a}_{30}, \mathrm{a}_{60}$, $\mathrm{HCT}, \mathrm{CMS}, \mathrm{pH}$, and the milk production traits (i.e., milk yield, SCC, and concentrations of protein, fat, casein, lactose, total solids, and urea) were discarded. Somatic cell score was calculated as $\log _{10}$ of SCC to normalize the distribution. Only data between 5 and 305 DIM for the first 10 parities were retained. Records were discarded from the database if greater than 3 standard deviations from the mean of the respective trait.

Cow breed composition was recorded in the national database and, for the purpose of the present study, was defined as the proportion of Holstein, Friesian, Jersey, Montbéliarde, Norwegian Red, and "other." Contemporary group of experimental treatment by test-date was defined for milk samples from cows in research herds, whereas contemporary group in the commercial herds was defined as herd-test-date. Contemporary groups with fewer than 10 observations were discarded. Following editing of the data, 136,807 milk samples from 
16,543 lactations from 9,824 dairy cows were available for further analyses.

Coefficients of heterosis and recombination loss were calculated for each cow using the following formulas (VanRaden and Sanders, 2003):

$$
\text { Heterosis }=1-\sum_{i=1}^{n} \text { sire }_{i} \times d a m_{i}
$$

and

$$
\text { Recombination loss }=1-\sum_{i=1}^{n} \frac{\operatorname{sire}_{i}^{2} \times d a m_{i}^{2}}{2},
$$

where sire $_{i}$ and $d a m_{i}$ are the proportion of genes of breed $i$ in the sire and dam, respectively.

\section{Statistical Analyses}

Pearson correlation coefficients (PROC CORR, SAS Institute Inc.) were computed between the milk composition and milk processing traits. Factors associated with each milk processing trait were determined using linear mixed animal models in ASREML (Gilmour et al., 2011). Fixed effects treated as categorical variables were parity ( 5 classes: first, second, third, fourth, and fifth and later parities), stage of lactation (10 classes: 5-30, 31-60, . . , 241-270, and 271-305 d postcalving), milking session (3 classes: a.m., p.m. for the research herds; combined a.m. + p.m. for the commercial herds), month of test (12 classes: January, ..., December), coefficient of heterosis (12 classes: $0,>0$ and $\leq 0.1, \ldots$, $>0.9$ and $<1,1)$, coefficient of recombination loss (12 classes: $0,>0$ and $\leq 0.1, \ldots,>0.9$ and $<1,1$ ), and the 2 -way interaction of parity $\times$ stage of lactation. The proportion of each breed (Friesian, Jersey, Montbéliarde, Norwegian Red, and other; Holstein was not included to avoid linear dependency in the model) was treated as a continuous variable. Random terms included the effect of test-day within lactation, within- and across-lactation effects, and the contemporary group. Preliminary analyses revealed that stage of lactation and month of test were not confounded owing to the presence of both autumn-calving (identified by a specific experimental treatment) and spring-calving cows; therefore, the reported least squares means for month of test were independent of the seasonality of the data. Supplementary analyses were undertaken when either test-day milk yield or milk protein concentration was included in the model as a covariate. In all instances, presented least squares means were for a reference animal of third parity, 100\% Holstein, milked in the morn- ing, averaged across all classes of stage of lactation and all calendar months of the year.

\section{RESULTS}

\section{Descriptive Statistics and Phenotypic Correlations}

The coefficient of variation $(\mathbf{C V})$ of milk yield was $57.14 \%$, whereas lesser variability was evident for milk composition; the CV for concentrations of protein, fat, casein, lactose, and total solids were 10.51, 23.26, $11.74,4.41$, and $8.99 \%$, respectively. Greater CV were observed for urea concentration (40.95\%) and SCS $(27.37 \%)$. Regarding milk processing characteristics, the CV of milk coagulation properties were $30.54 \%$ (RCT), $29.43 \%\left(\mathrm{k}_{20}\right), 24.09 \%\left(\mathrm{a}_{30}\right)$, and $12.33 \%\left(\mathrm{a}_{60}\right)$. The CV for HCT, CMS, and $\mathrm{pH}$ were $64.80,7.32$, and $1.20 \%$, respectively. The summary statistics relative to the reference animal used to derive the least squares means in the current study are presented in Table 1.

Pearson correlation coefficients between milk yield, milk composition, SCS, and milk processing characteristics are in Table 2. The correlations between milk yield and the milk technological traits were generally weak, ranging from -0.37 (between milk yield and $\mathrm{a}_{30}$ ) to 0.33 (between milk yield and $\mathrm{k}_{20}$ ). Regarding the nitrogen fraction of the milk, the strongest correlations were between protein concentration and $\mathrm{k}_{20}(-0.59)$ and between protein concentration and $\mathrm{a}_{30}(0.54)$. A moderate negative correlation was evident between RCT and $\mathrm{a}_{30}$ $(-0.54)$, whereas a strong negative correlation existed between $\mathrm{k}_{20}$ and $\mathrm{a}_{30}(-0.89)$. Heat coagulation time was positively correlated with both milk urea $(0.24)$ and CMS (0.17) but negatively correlated $(-0.19)$ with $\mathrm{pH}$. A strong positive correlation existed between RCT and $\mathrm{pH}$ (0.66), whereas only a weak correlation was evident between CMS and RCT (0.22).

\section{Factors Associated with Milk Processing Characteristics}

Categorical fixed effects associated with all the milk processing characteristics included month of test $(P<$ $0.001)$, milking session $(P<0.001)$, parity $(P<0.001)$, stage of lactation $(P<0.001)$, and a 2 -way interaction parity $\times$ stage of lactation $(P<0.001)$. Heterosis was associated $(P<0.05)$ with $\mathrm{HCT}$, CMS, and $\mathrm{pH}$, and recombination loss was associated $(P<0.05)$ with RCT, $\mathrm{k}_{20}, \mathrm{a}_{30}$, and $\mathrm{pH}$. Milk processing characteristics were associated $(P<0.01)$ with the proportion of Norwegian Red (with the exception of CMS), Friesian, and Jersey. The proportion of Montbéliarde was associated only with CMS and $\mathrm{pH}(P<0.05)$. 
Table 2. Pearson correlation coefficients between milk yield, milk composition, SCS, and milk technological traits

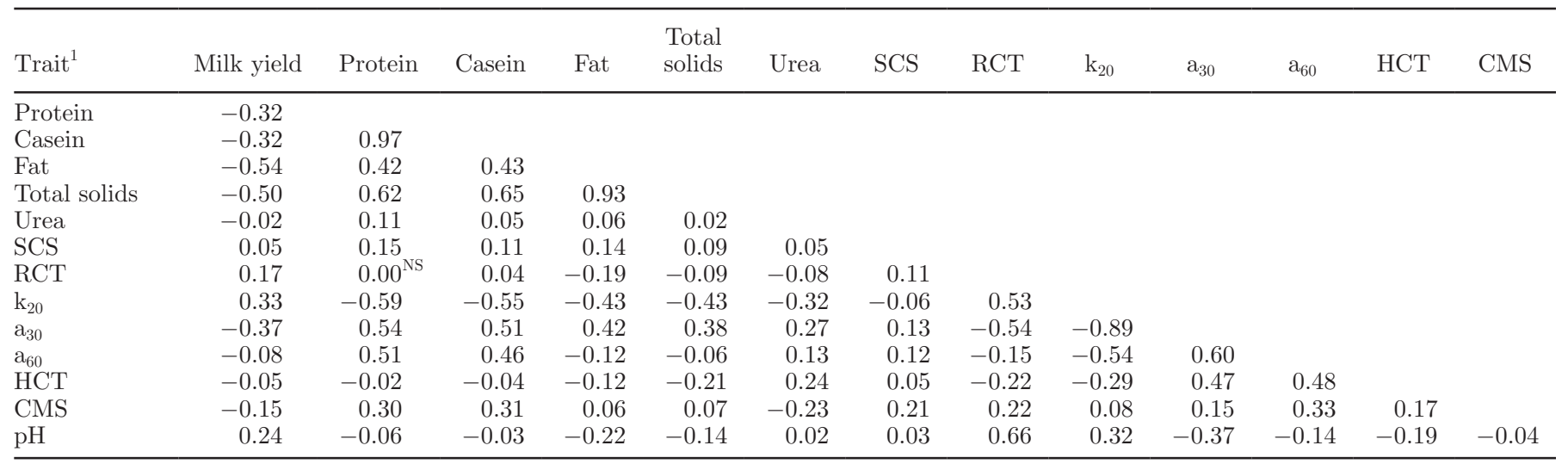

${ }^{1} \mathrm{SCS}=\log _{10}(\mathrm{SCC}) ; \mathrm{RCT}=$ rennet coagulation time; $\mathrm{k}_{20}=$ curd-firming time; $\mathrm{a}_{30}$ and $\mathrm{a}_{60}=$ curd firmness 30 min and 60 min after rennet addition to milk, respectively; $\mathrm{HCT}=$ heat coagulation time; CMS = casein micelle size.

${ }^{\mathrm{NS}}$ Correlation not different from zero $(P>0.05)$.

Milk Coagulation Properties. The least squares means for RCT, $\mathrm{k}_{20}, \mathrm{a}_{30}$, and $\mathrm{a}_{60}$ indicated poor coagulation ability (i.e., long RCT and weak $\mathrm{a}_{30}$ ) in January, followed by an improvement in February that persisted until June $(P<0.001$; Figure 1$)$; all milk coagulationrelated traits subsequently deteriorated until September $(P<0.001)$, but improved again until the end of the calendar year $(P<0.001 ;$ Figure 1$)$. Milk collected from the p.m. milking session, relative to the a.m. session, was characterized by superior coagulation ability, as evidenced by stronger $\mathrm{a}_{30}$ and shorter RCT $(P<$ 0.001; data not shown). Relative to a Holstein cow, a greater proportion of Friesian, Jersey, and Norwegian Red was associated with improved coagulation ability $(P<0.001$; Table 3). Jersey cows had the best milk coagulation-related traits $(P<0.001)$ but, when average protein percentage was included as a covariate in the model, the previously detected superiority in either $\mathrm{k}_{20}$ or $\mathrm{a}_{30}$ of the Jersey relative to both Norwegian Red and Friesian no longer existed $(P>0.05$; data not shown). Milk coagulation properties were most favorable in animals with a recombination rate between 40 and $50 \%(P<0.05)$.

Milk coagulation properties were more favorable, on average, for primiparous animals $(P<0.001$; Figure $2)$. Irrespective of cow parity, at the very start of lactation, RCT and $\mathrm{k}_{20}$ were both short, and $\mathrm{a}_{30}$ was strong (Figure 2). Rennet coagulation time deteriorated $(P<$ 0.001) until mid lactation, with the 2 -way interaction between parity and stage of lactation manifesting itself as an earlier peak in RCT for primiparae (121-150 DIM) relative to multiparae (91-120 DIM; Figure 2). Overall, $\mathrm{a}_{30}$ deteriorated $(P<0.001)$ until 31 to 60 DIM, but subsequently improved until the end of lactation for all cow parities $(P<0.001$; Figure 2$)$. However, a 2 -way interaction of parity $\times$ stage of lactation ex- isted, resulting in a lesser nadir $\mathrm{a}_{30}$ from 31 to $60 \mathrm{DIM}$ for multiparae compared with primiparae $(P<0.001$; Figure 2). Irrespective of cow parity, when models were adjusted for protein percentage, the recovery in either $\mathrm{k}_{20}$ or $\mathrm{a}_{30}$ after peak of lactation was no longer obvious, whereas adjustment for milk yield in the multiple regression models did not affect the lactation profile or the significance of the multiple regression coefficients for breed proportions of any coagulation-related trait.

Heat Coagulation Time. Milk HCT was, on average, lowest in January $(5.29 \mathrm{~min}, \mathrm{SE}=0.78)$ but remained relatively constant $(P>0.05)$ until September $(P<0.01 ; 6.85 \mathrm{~min}, \mathrm{SE}=0.17)$, after which it increased until the end of the calendar year $(P<0.001$; data not shown). Milk HCT was greater $(P<0.001)$ in the a.m. milking $(6.81 \mathrm{~min}, \mathrm{SE}=0.09)$ compared with the p.m. milking session (5.99 min, $\mathrm{SE}=0.09$; data not shown). Relative to Holstein, a greater proportion of Jersey was associated with reduced HCT ( $P$ $<0.01$; Table 3). Milk HCT increased with increasing proportion of Friesian or Norwegian Red breed $(P<$ 0.01 ; Table 3$)$. The effect of heterosis coefficient was of little biological importance. Primiparous cows had the greatest HCT $(P<0.001 ; 7.61 \mathrm{~min}, \mathrm{SE}=0.09$; Figure 3). On average, HCT peaked around mid lactation (121-150 DIM) irrespective of animal parity; at both the start and end of lactation, milk was less suitable for heat treatment $(P<0.001$; Figure 3$)$. The 2 -way interaction between parity and stage of lactation manifested as a less-evident reduction in $\mathrm{HCT}$ in late lactation for primiparae compared with multiparae $(P$ $<0.001$; Figure 3).

Casein Micelle Size. Least squares means for CMS decreased $(P<0.001)$ from January $(172.60 \mathrm{~nm}$, SE $=1.83)$ to March $(166.03 \mathrm{~nm}, \mathrm{SE}=0.49)$ and subsequently increased until June $(P<0.001 ; 170.82 \mathrm{~nm}, \mathrm{SE}$ 


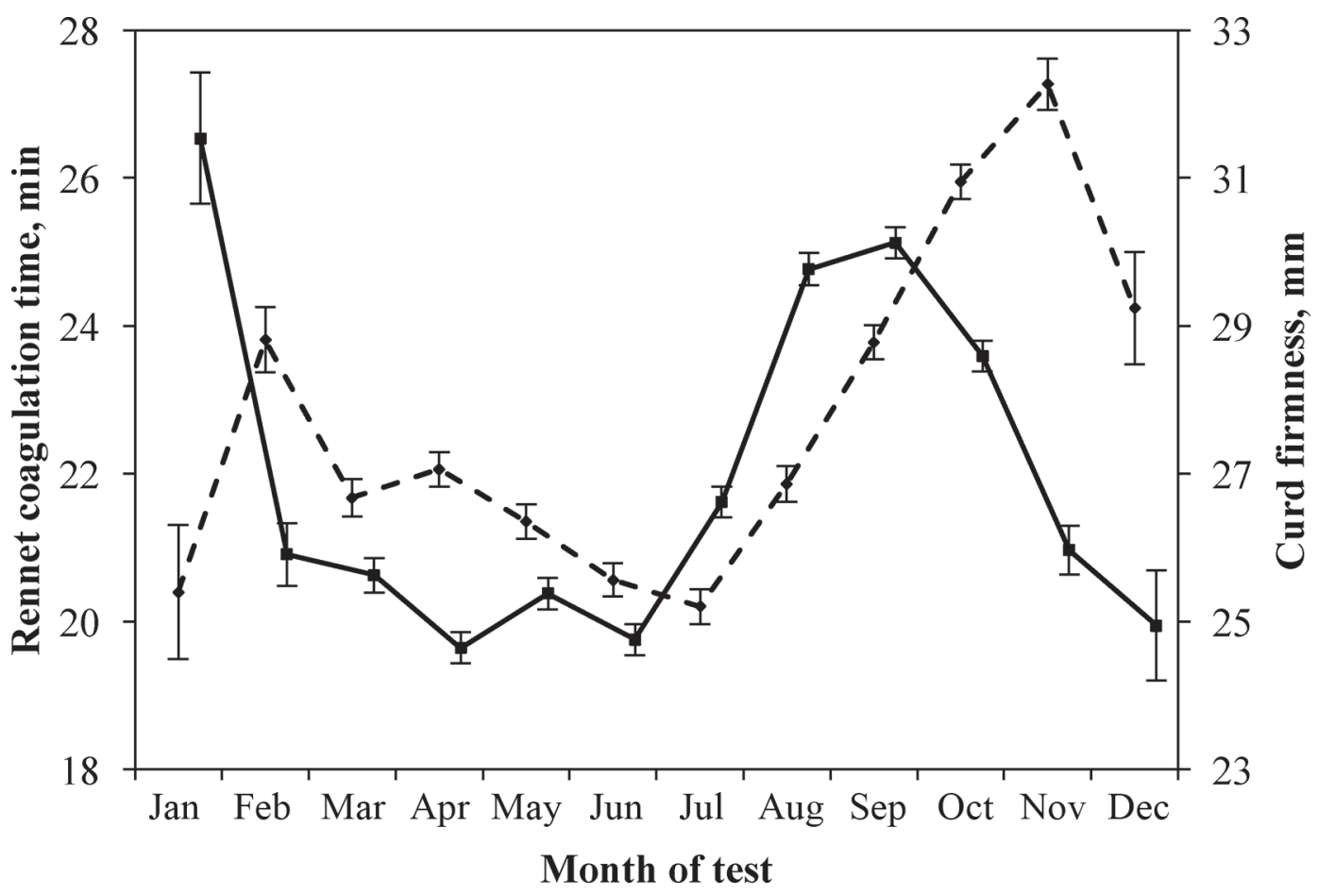

Figure 1. Least squares means (with standard error bars) for rennet coagulation time (- - - ) and curd firmness 30 min after rennet addition to milk (------) across month of test.

$=0.43)$. Casein micelle size declined again in July $(P<$ $0.001 ; 165.82 \mathrm{~nm}, \mathrm{SE}=0.44)$ but subsequently peaked in September $(P<0.001 ; 176.74 \mathrm{~nm}, \mathrm{SE}=0.44)$, after which it declined $(P<0.001$; data not shown). Linear regression coefficients from the multiple regression models were negative for Jersey, Friesian, and Montbéliarde $(P<0.05$; Table 3$)$. Although significant $(P$ $<0.05$ ), the contribution of heterosis coefficient was biologically small. The lowest CMS was evident for primiparous cows $(P<0.001 ; 169.39 \mathrm{~nm}, \mathrm{SE}=0.29)$, increasing with parity number, although mean CMS remained relatively constant after parity $3(P>0.05$; data not shown). Within lactation, milk CMS increased consistently $(P<0.001)$ with stage of lactation but CMS of primiparae plateaued in late lactation (211-305 DIM), resulting in a 2-way interaction of parity and stage of lactation (data not shown).

Milk $\boldsymbol{p H}$. Least squares means for milk $\mathrm{pH}$ reduced $(P<0.001)$ from January $(6.81, \mathrm{SE}=0.01)$ to July $(6.68, \mathrm{SE}=0.003)$, but remained relatively constant for the remainder of the calendar year, varying between $6.70(\mathrm{SE}=0.004)$ and $6.73(\mathrm{SE}=0.003)$ in November and September, respectively (data not shown). Milk pH from the p.m. milking session was lower $(\mathrm{pH}=6.68, \mathrm{SE}$

Table 3. Regression coefficients (SE in parentheses) of milk coagulation traits, ${ }^{1}$ casein micelle size, and $\mathrm{pH}$ on the proportion of each breed (Holstein was considered the reference breed) estimated from the multiple regression model

\begin{tabular}{lccccc}
\hline Trait $^{1}$ & Holstein & Friesian & Jersey & Montbéliarde & Norwegian Red \\
\hline $\mathrm{RCT}$, min & $0^{\mathrm{a}}$ & $-2.10^{\mathrm{b}}(0.28)$ & $-4.59^{\mathrm{c}}(0.24)$ & $0.51^{\mathrm{a}}(0.42)$ & $-1.77^{\mathrm{b}}(0.36)$ \\
$\mathrm{k}_{20}$, min & $0^{\mathrm{a}}$ & $-0.60^{\mathrm{b}}(0.10)$ & $-1.85^{\mathrm{c}}(0.08)$ & $0.14^{\mathrm{a}}(0.14)$ & $-0.52^{\mathrm{b}}(0.12)$ \\
$\mathrm{a}_{30}, \mathrm{~mm}$ & $0^{\mathrm{a}}$ & $2.23^{\mathrm{b}}(0.35)$ & $6.21^{\mathrm{c}}(0.31)$ & $-0.90^{\mathrm{a}}(0.52)$ & $2.23^{\mathrm{b}}(0.45)$ \\
$\mathrm{a}_{60}, \mathrm{~mm}$ & $0^{\mathrm{a}}$ & $0.41^{\mathrm{b}}(0.17)$ & $1.97^{\mathrm{c}}(0.14)$ & $-0.34^{\mathrm{a}}(0.25)$ & $1.09^{\mathrm{d}}(0.21)$ \\
$\mathrm{HCT}, \min$ & $0^{\mathrm{a}}$ & $0.44^{\mathrm{b}}(0.16)$ & $-0.37^{\mathrm{c}}(0.14)$ & $0.20^{\mathrm{abd}}(0.24)$ & $0.80^{\mathrm{bd}}(0.21)$ \\
$\mathrm{CMS}, \mathrm{nm}$ & $0^{\mathrm{a}}$ & $-1.88^{\mathrm{b}}(0.61)$ & $-4.54^{\mathrm{c}}(0.53)$ & $-1.99^{\mathrm{b}}(0.90)$ & $0.99^{\mathrm{a}}(0.79)$ \\
$\mathrm{pH}$ & $0^{\mathrm{a}}$ & $-0.02^{\mathrm{bd}}(0.003)$ & $-0.01^{\mathrm{b}}(0.003)$ & $0.01^{\mathrm{c}}(0.005)$ & $-0.03^{\mathrm{d}}(0.004)$ \\
\hline
\end{tabular}

${ }^{\mathrm{a}-\mathrm{d}}$ Values within rows with different superscripts differ $(P<0.05)$.

${ }^{1} \mathrm{RCT}=$ rennet coagulation time; $\mathrm{k}_{20}=$ curd-firming time; $\mathrm{a}_{30}$ and $\mathrm{a}_{60}=$ curd firmness 30 and 60 min after rennet addition to milk, respectively; $\mathrm{HCT}=$ heat coagulation time; $\mathrm{CMS}=$ casein micelle size. 

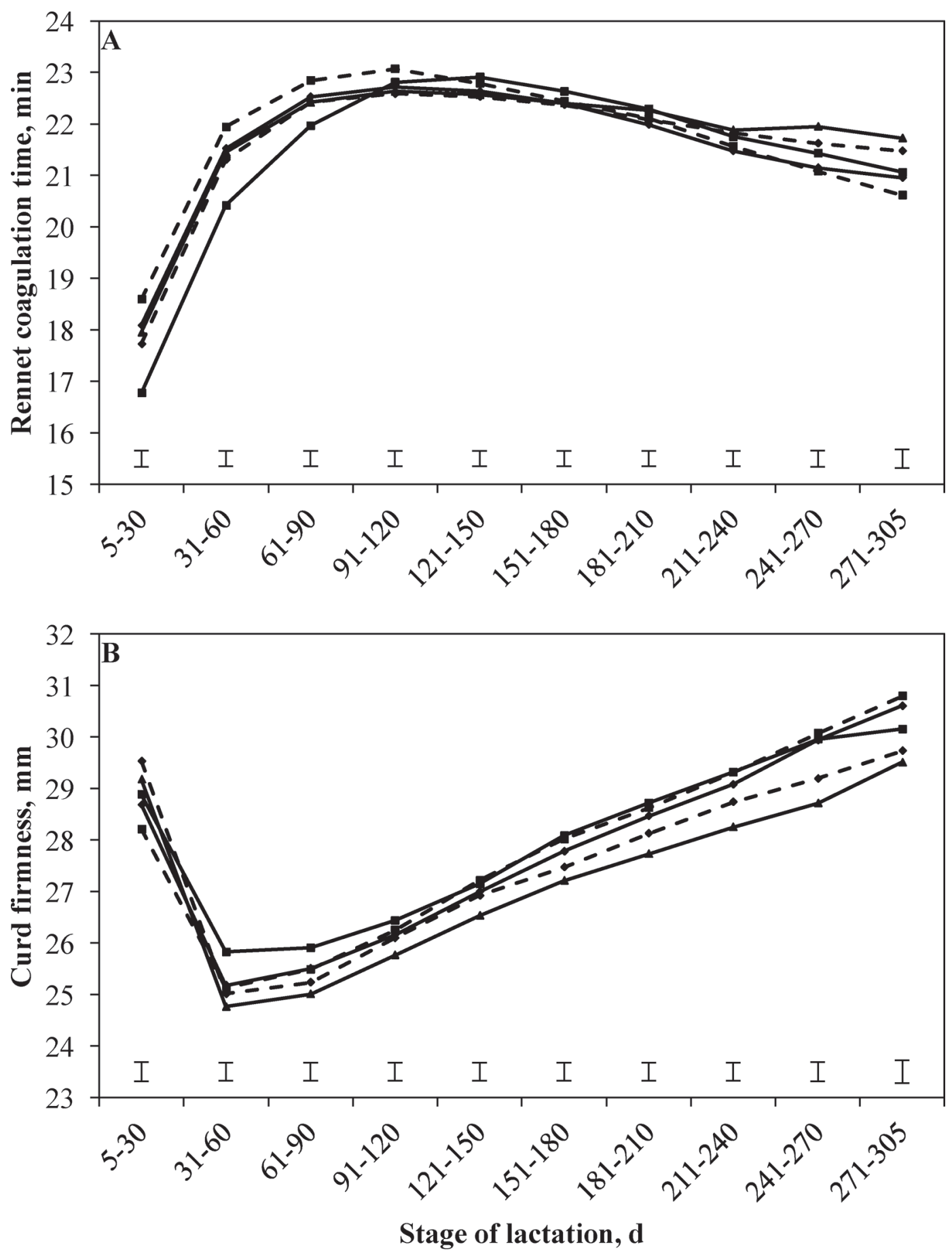

Figure 2. Least squares means for (A) rennet coagulation time, and (B) curd firmness 30 min after rennet addition to milk across stage of lactation for parity $1(-\mathbf{-})$, parity $2(--\mathbf{-}--)$, parity $3(--)$, parity $4\left(---_{--)}\right.$, and parity $\geq 5(-\mathbf{\Delta}-)$. The error bars represent the mean SE per stage of lactation across parities.

$=0.002)$ than milk $\mathrm{pH}$ from the a.m. milking session $(P<0.001 ; \mathrm{pH}=6.71, \mathrm{SE}=0.002)$. An increased proportion of Friesian, Jersey, and Norwegian Red was associated with lower $\mathrm{pH}$ relative to the Holstein $(P$
$<0.001$; Table 3). The contributions of both heterosis and recombination loss coefficient were biologically small. Milk $\mathrm{pH}$ was lowest for primiparous cows $(P<$ $0.001 ; 6.69, \mathrm{SE}=0.002$; Figure 3$)$. On average, milk 

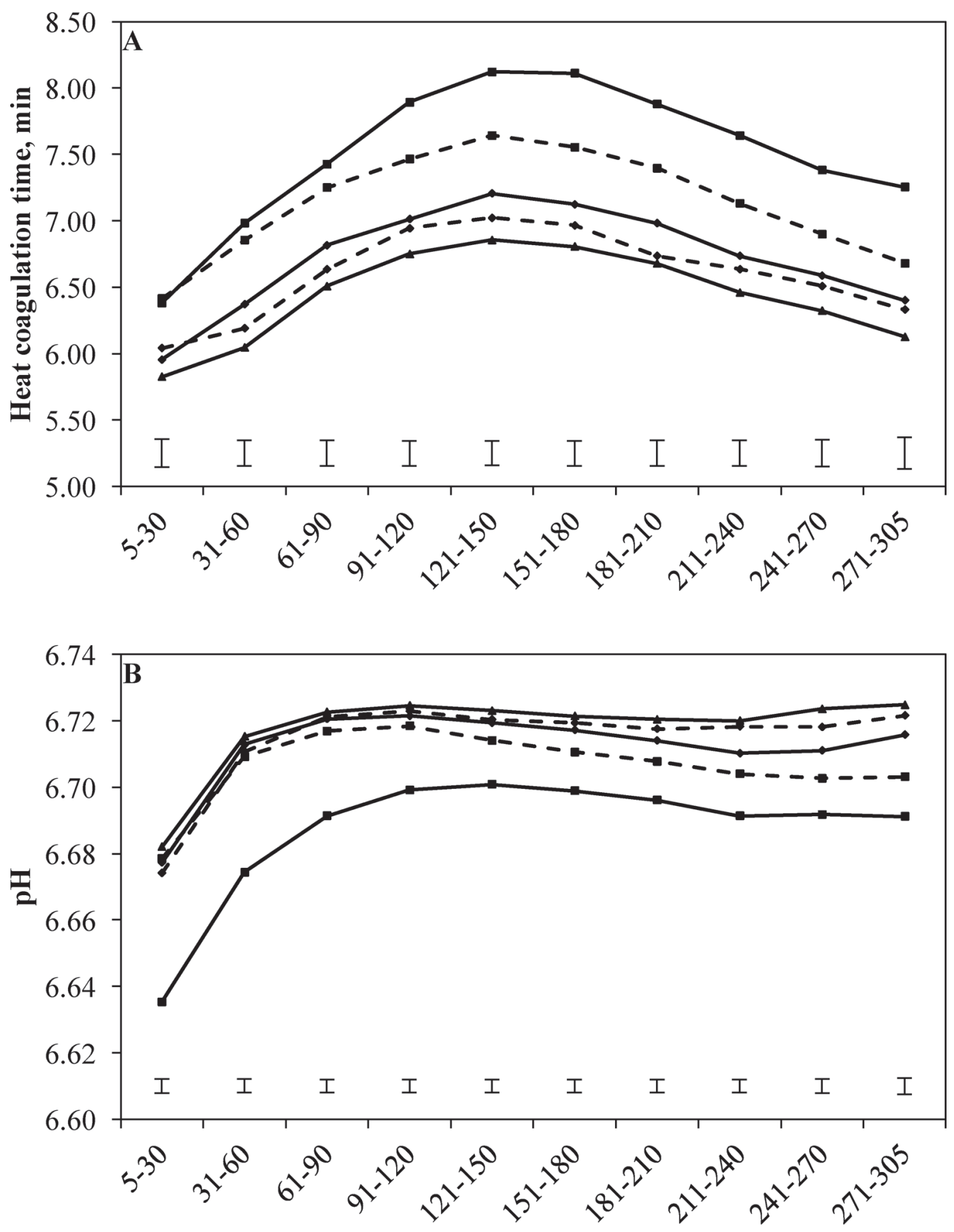

Stage of lactation, $d$

Figure 3. Least squares means for (A) heat coagulation time, and (B) milk pH across stage of lactation for parity 1 (- - - ), parity 2 $(----)$, parity $3(--)$, parity $4(---)$, and parity $\geq 5(-\mathbf{-})$. The error bars represent the mean SE per stage of lactation across parities.

pH peaked between 91 and 120 DIM, which persisted to the end of lactation irrespective of cow parity (Figure 3 ). The observed effect of the 2 -way interaction parity $\times$ stage of lactation, although significant $(P<0.001)$, was biologically small (Figure 3).

\section{DISCUSSION}

The objective of the present study was to identify factors associated with the variability in milk processing traits, predicted by mid-infrared spectroscopy, on 
a large population of dairy cows in a seasonal-calving, grass-based dairy production system. Results clearly demonstrated that variability existed among animals due to animal breed composition, parity, and stage of lactation; the differences among cow characteristics even persisted after adjustment for differences in cow milk yield. Milk processability also varied across the calendar months of test and between morning and evening milkings.

The correlations between milk coagulation properties in the present study were all consistent with previous reports that investigated milk coagulation properties at both the phenotypic and genetic level in dairy cows (Ikonen et al., 2004; Cassandro et al., 2008; Vallas et al., 2010). The positive correlation between RCT and CMS in the present study corroborates Chen et al. (2014), based on 550 individual milk samples from UK Holstein cows, and the positive correlation between urea concentration and $\mathrm{HCT}$ in the present study was similar to findings of Singh (2004) and Reid et al. (2015) in dairy cows.

\section{Effect of National Herd Breed Composition on the National Milk Pool}

The contribution of breed differences to variability in milk composition have previously been reported in both grazed grass-fed (Auldist et al., 2002; Sneddon et al., 2016) and TMR-fed (Barłowska et al., 2014) dairy cows, demonstrating that milk yielded by Jersey cows had greater protein concentration than milk of Holstein cows. Evidence from the present study indicated that the superior milk coagulation property of Jersey cows relative to the Holstein contemporaries was not solely due to the higher milk protein concentration typical of Jerseys, which in the present study was $4.10 \%$. Therefore, it appears that Holsteins may have a genetic predisposition to inferior milk clotting characteristics over and above their genetic merit for protein concentration. This hypothesis was supported by Caroli et al. (2009), who identified a polymorphism in the gene coding for $\kappa$-casein $\left(C S N 3^{*} E\right)$ in Holstein-Friesian cows with an unfavorable association with milk coagulation ability. Geary et al. (2010) suggested that Jersey cows could potentially yield more cheese per unit of milk compared with Holsteins. However, the greater milk yield of Holstein cows $(5,217 \mathrm{~kg})$ compared with Jersey contemporaries $(4,230 \mathrm{~kg}$ ) reported by Coffey et al. (2016) could offset the lower cheese production per unit of milk from the Jerseys, a conclusion also supported by Sneddon et al. (2016). A possible short-term strategy to improve coagulation-related traits at the industry level could be to blend milk produced by Holstein-Friesians with milk yielded by Jerseys. Such a strategy was also suggested by Bland et al. (2015), who demonstrated a positive (quadratic) relationship between curd firmness and the proportion of Jersey milk.

Milk HCT of the different cow breeds studied in the present study was similar to results reported by Barłowska et al. (2014) in Polish Holstein-Friesian, Jersey, and Simmental cows, despite the Polish cows being fed TMR. At an industry level, most heat stability problems occur when milk is fortified with additives, such as minerals ( $\mathrm{Ca}, \mathrm{Mg}$, and $\mathrm{Zn}$ ), or cocoa and tea extracts (Singh, 2004), which normally have a negative effect on resistance to heat treatment. Given the lower HCT of Jersey milk as observed in the present study, blending Jersey milk with milk from other breeds may have implications for the heat stability of milk processed. To our knowledge, no evidence exists on the effect on milk heat stability of blending milk produced by different cow breeds.

\section{The Increasing Need for Dairy Products and Implications for the Dairy Processing Industry}

Expansion in herd size, coupled with increased productivity, is required to satisfy the increasing world demand for milk and dairy products (Alexandratos and Bruinsma, 2012). In Irish spring-calving dairy herds, rate of herd expansion is associated with a reduction in herd-average parity number (Jago and Berry, 2011); moreover, given the abolition of milk quota in the European Union, it is anticipated that herd size in Ireland will increase at an annual rate of 3\% (Dillon, 2011). Therefore, in the medium term, the contribution of milk from lesser-parity cows to the national milk pool is likely to increase. Results from the present study indicated that, irrespective of the final output of milk processing, milk produced by young cows had improved processability both for cheese manufacturing (i.e., shorter RCT and greater $\mathrm{a}_{30}$ ) and for milk powder production (i.e., greater HCT). Therefore, a general improvement of milk processability may be expected in the following years, which could improve the profitability of the entire dairy sector. This is important when interpreting national trends in milk quality so as not to attribute the improvement in milk quality solely to improvements in management and genetic merit over that period; improvements in milk processing characteristics are expected to slow as the rate of expansion slows or comes to a halt.

\section{Seasonal Variability in Milk Processing Characteristics and Implications for the Dairy Processing Sector}

The variability in milk coagulation properties across lactation documented in the present study corroborates 
previous international studies by Penasa et al. (2014) in Italian Holstein-Friesian, Brown Swiss, and Simmental dairy cows, by Ikonen et al. (2004) in Finnish Ayrshires, and by Vallas et al. (2010) in Estonian Holsteins. Such variability has implications in countries where seasonal calving predominates, such as in Ireland and New Zealand, but also to a lesser extent in other countries such as Australia and the UK. Indeed, seasonal calving implies seasonality of milk supply and quality. For instance, in Ireland, the greatest proportion ( $80 \%$; Berry et al., 2013) of dairy farms concentrate calvings between January and April, inclusive, of each calendar year. The aim of this production system is to synchronize the onset of the lactation with the initiation of grass growth to maximize the utilization of low-cost grazed pasture in the diet (Berry et al., 2013). The multiple regression model proposed in the present study accounted for both stage of lactation and calendar month, implying that model solutions for both effects could be considered additive; disentangling of the effects was possible because of the inclusion of autumn-calving cows $(6.90 \%$ of the data) in the analysis in the present study. The observed variability in milk quality across calendar months might therefore reflect changes in quantity and quality of the diet fed; at the start and end of the calendar year in Ireland, cows are generally indoors and fed mainly grass silage (O'Brien et al., 1999). Changes in diet and housing system are known to be associated with changes in milk SCC, total bacteria count, and laboratory pasteurization count (O'Connell et al., 2015), which in turn could affect the respective milk processability. The consequence of seasonal milk supply and quality is less relevant in countries with year-round calving systems and therefore the supply (and quality) of the herd milk pool fluctuates less throughout the year. The variability in milk processing attributes across the year in seasonal-calving herds, nonetheless, represents important challenges for dairy processors in their attempts to ensure product consistency.

In a scenario when the final output of milk processing is cheese, short reactivity to rennet addition and strong curd-firming capacity are desired characteristics. Indeed, a positive association exists between curd firmness and Cheddar cheese yield (Bynum and Olson, 1982; Johnson et al., 2001). Strong curd firmness is also associated with improved cheese yield for cheese intended for long maturation before human consumption, as evidenced by Aleandri et al. (1989) in the production of Parmigiano Reggiano and Pretto et al. (2013) in the production of Grana Padano. To our knowledge, only one formula considers $\mathrm{a}_{30}$ as a predictor of cheese yield, and it was implemented by Aleandri et al. (1989) for the prediction of Parmigiano Reggiano cheese yield, and therefore is not directly applicable to the national production system due to differences in cheesemaking processes. However, the linear regression coefficient of $a_{30}$ on casein content, which is a predictor of cheese yield (Van Slyke and Price, 1949), in the multiple regression model developed in the present study, was 0.04 units. Therefore, assuming a milk fat level of 3.90\% and a water content of full-fat Cheddar cheese of $37.7 \%$ (Fenelon and Guinee, 1999), milk produced by early lactation cows (5-30 DIM) would yield $2.20 \%$ more cheese than milk produced by cows at peak lactation (31-60 DIM), when $\mathrm{a}_{30}$ was the lowest.

In direct contrast, in a scenario where the main objective of the milk processor is to extend milk shelf life through heat treatments, resistance to high temperature is a desired characteristic. Results from the present study indicated that a higher HCT was achieved in mid lactation, suggesting that processors can potentially reduce the propensity of milk to fouling and thus increase production times for manufacture of skim and whole milk powder in this lactation period, when coagulation-related traits are less favorable for cheese production. This trend was also documented by Sneddon et al. (2016), modeling supply lactation curves for yields of dairy products of 1,073 Holstein, 726 Jersey, and 2,534 Holstein $\times$ Jersey crossbred first-lactation, seasonal-calving cows in New Zealand.

Finally, animal breeding may contribute to enhancing the manufacturing characteristics of milk (Cassandro et al., 2008; Tiezzi et al., 2013). Therefore, access to routinely measurable (cost-effective, rapid, and accurate) phenotypes is becoming increasingly important to achieve genetic gain and provide processors with a more detailed knowledge of the trait(s) of interest (Berry, 2015). Infrared spectroscopy, through the exploitation of interactions between infrared radiation and sample molecules, is the most commonly used technique to provide quick and low-cost measurements of milk composition, and has recently been highlighted as an indicator of milk quality (De Marchi et al., 2014; McDermott et al., 2016a,b) and animal production traits (McParland and Berry, 2016), including dairy cow health and fertility (Bastin et al., 2016).

\section{CONCLUSIONS}

A particular aspect that emerged from the present study was that, in general, characteristics associated with more favorable milk heat stability were associated with those less favorable for cheese production. Furthermore, breeds yielding milk with better heat stability were least suitable for cheese-making. These results could help processors to manage their processing systems, especially in countries characterized by seasonal supply of fresh milk, and manage their prod- 
uct portfolio while accounting for variation in processing characteristics. The inclusion of milk processability traits in the national breeding goal may be of interest to stakeholders. However, genetic variation of milk processability and correlations with milk yield, fat and protein yield and concentration, as well as the economic value attributable to milk processability require further quantification.

\section{ACKNOWLEDGMENTS}

Funding for the current study was received from the Irish Department of Agriculture, Food and the Marine, Research Stimulus Fund project 11/SF/311, Breed Quality. Laboratory technical support by Bernard Corrigan, Jim Flynn, Owen Kenny, and Paula O'Connor (Teagasc, Moorepark, Fermoy, Co. Cork, Ireland) is gratefully acknowledged.

\section{REFERENCES}

Aleandri, R., J. C. Schneider, and L. G. Buttazzoni. 1989. Evaluation of Formagraph for cheese production based on milk characteristics and Formagraph measures. J. Dairy Sci. 72:1967-1975.

Alexandratos, N., and J. Bruinsma. 2012. World agriculture towards 2030/2050: The 2012 revision. ESA Working paper No. 12-03. Food and Agriculture Organization of the United Nations, Rome, Italy.

Auldist, M. J., C. Mullins, B. O'Brien, B. T. O'Kennedy, and T. Guinee. 2002. Effect of cow breed on milk coagulation properties. Milchwissenschaft 57:140-143.

Barłowska, J., Z. Litwińczuk, and M. Kowal. 2014. Influence of production season and lactation stage on the technological suitability of milk from cows of various breeds fed in the TMR system. Ann. Anim. Sci. 14:649-661.

Bastin, C., L. Théron, A. Lainé, and N. Gengler. 2016. On the role of mid-infrared predicted phenotypes in fertility and health dairy breeding programs. J. Dairy Sci. 99:4080-4094.

Berry, D. P. 2015. Breeding the cow of the future: What do we need? Anim. Prod. Sci. 55:823-837.

Berry, D. P., J. F. Kearney, K. Twomey, and R. D. Evans. 2013. Genetics of reproductive performance in seasonal calving dairy cattle production systems. Ir. J. Agric. Food Res. 52:1-16.

Bland, J. H., A. S. Grandison, and C. C. Fagan. 2015. The effect of blending Jersey and Holstein-Friesian milk on composition and coagulation properties. Int. J. Dairy Technol. 68:454-457.

Brereton, R. G. 2015. The Mahalanobis distance and its relationship to principal components scores. J. Chemometr. 29:143-145.

Bynum, D. G., and N. F. Olson. 1982. Influence of curd firmness at cutting on Cheddar cheese yield and recovery of milk constituents. J. Dairy Sci. 65:2281-2290.

Caroli, A. M., S. Chessa, and G. J. Erhardt. 2009. Invited review: Milk protein polymorphism in cattle: Effect on animal breeding and human nutrition. J. Dairy Sci. 92:5335-5352.

Cassandro, M., A. Comin, M. Ojala, R. Dal Zotto, M. De Marchi, L. Gallo, P. Carnier, and G. Bittante. 2008. Genetic parameters of milk coagulation properties and their relationships with milk yield and quality traits in Italian Holstein cows. J. Dairy Sci. 91:371376 .

Chen, B., M. J. Lewis, and A. S. Grandison. 2014. Effect of seasonal variation on the composition and properties of raw milk destined for processing in the UK. Food Chem. 158:216-223.

Coffey, E. L., B. Horan, R. D. Evans, and D. P. Berry. 2016. Milk production and fertility performance of Holstein, Friesian, and Jer- sey purebred cows and their respective crosses in seasonal-calving commercial farms. J. Dairy Sci. 99:5681-5689.

De Marchi, M., R. Dal Zotto, M. Cassandro, and G. Bittante. 2007. Milk coagulation ability of five dairy cattle breeds. J. Dairy Sci. 90:3986-3992.

De Marchi, M., V. Toffanin, M. Cassandro, and M. Penasa. 2014. Invited review: Mid-infrared spectroscopy as phenotyping tool for milk traits. J. Dairy Sci. 97:1171-1186.

Devold, T. G., M. J. Brovold, T. Langsrud, and G. E. Vegarud. 2000. Size of native and heated casein micelles, content of protein and minerals in milk from Norwegian Red cattle - Effect of milk protein polymorphism and different feeding regimens. Int. Dairy J. 10:313-323.

Dillon, P. 2011. The Irish dairy industry-Planning for 2020. The Irish dairy industry: To 2015 and beyond. Accessed July 18 2016. http://agresearch.teagasc.ie/moorepark/publications/pdfs/ Dairy_Conference_Proceedings_2011.pdf\#page $=5$.

Fenelon, M. A., and T. P. Guinee. 1999. The effect of milk fat on Cheddar cheese yield and its prediction, using modification of the Van Slyke cheese formula. J. Dairy Sci. 82:2287-2299.

Formaggioni, P., A. Summer, P. Franceschi, M. Malacarne, and P. Mariani. 2008. Cheese yield: factors of variation and predictive formulas. A review focused particularly on Grana type cheese. Ann. Fac. Med. Vet. Parma 28:211-232.

Geary, U., N. Lopez-Villalobos, D. J. Garrick, and L. Shalloo. 2010. Development and application of a processing model for the Irish dairy industry. J. Dairy Sci. 93:5091-5100.

Gilmour, A. R., B. R. Cullis, S. J. Welham, and R. Thompson. 2011. ASREML Reference Manual. VSN International Ltd., Hemel Hempstead, UK.

Glantz, M., T. G. Devold, G. E. Vegarud, H. Lindmark Månsson, H. Stålhammar, and M. Paulsson. 2010. Importance of casein micelle size and milk composition for milk gelation. J. Dairy Sci. 93:1444-1451.

Hewavitharana, A. K., and B. V. Brakel. 1997. Fourier transform infrared spectrometric method for rapid determination of casein in raw milk. Analyst (Lond.) 122:701-704.

Ikonen, T., S. Morri, A.-M. Tyrisevä, O. Ruottinen, and M. Ojala. 2004. Genetic and phenotypic correlations between milk coagulation properties, milk production traits, somatic cell count, casein content, and pH of milk. J. Dairy Sci. 87:458-467.

Jago, J. G., and D. P. Berry. 2011. Associations between herd size, rate of expansion and production, breeding policy and reproduction in spring-calving dairy herds. Animal 5:1626-1633.

Johnson, M. E., C. M. Chen, and J. J. Jaeggi. 2001. Effect of rennet coagulation time on composition, yield, and quality of reduced-fat Cheddar cheese. J. Dairy Sci. 84:1027-1033.

McDermott, A., G. Visentin, M. De Marchi, D. P. Berry, M. A. Fenelon, P. M. O'Connor, O. A. Kenny, and S. McParland. 2016a. Prediction of individual milk proteins including free amino acids in bovine milk using mid-infrared spectroscopy and their correlations with milk processing characteristics. J. Dairy Sci. 99:3171-3182.

McDermott, A., G. Visentin, S. McParland, D. P. Berry, M. A. Fenelon, and M. De Marchi. 2016b. Effectiveness of mid-infrared spectroscopy to predict the color of bovine milk and the relationship between milk color and traditional milk quality traits. J. Dairy Sci. 99:3267-3273.

McLean, D. M., E. R. Bruce Graham, R. W. Ponzoni, and H. A. McKenzie. 1987. Effect of milk protein genetic variants and composition on heat stability of milk. J. Dairy Res. 54:219-235.

McParland, S., and D. P. Berry. 2016. The potential of Fourier transform infrared spectroscopy of milk samples to predict energy intake and efficiency in dairy cows. J. Dairy Sci. 99:4056-4070.

O'Brien, B., R. Mehra, J. F. Connolly, and D. Harrington. 1999. Seasonal variation in the composition of Irish manufacturing and retail milks: 1. Chemical composition and renneting properties. Ir. J. Agric. Food Res. 38:53-64.

O'Connell, A., S. McParland, P. L. Ruegg, B. O'Brien, and D. Gleeson. 2015. Seasonal trends in milk quality in Ireland between 2007 and 2011. J. Dairy Sci. 98:3778-3790. 
Penasa, M., F. Tiezzi, A. Sturaro, M. Cassandro, and M. De Marchi 2014. A comparison of the predicted coagulation characteristics and composition of milk from multi-breed herds of Holstein-Friesian, Brown Swiss and Simmental cows. Int. Dairy J. 35:6-10.

Poulsen, N. A., H. P. Bertelsen, H. B. Jensen, F. Gustavsson, M. Glantz, H. Lindmark Månsson, A. Andrén, M. Paulsson, C. Bendixen, A. J. Buitenhuis, and L. B. Larsen. 2013. The occurrence of noncoagulating milk and the association of bovine milk coagulation properties with genetic variants of the caseins in 3 Scandinavian dairy breeds. J. Dairy Sci. 96:4830-4842.

Pretto, D., M. De Marchi, M. Penasa, and M. Cassandro. 2013. Effect of milk composition and coagulation traits on Grana Padano cheese yield under field conditions. J. Dairy Res. 80:1-5.

Reid, M., M. O'Donovan, C. T. Elliott, J. S. Beiley, C. J. Watson, S. T. J. Lalor, B. Corrigan, M. A. Fenelon, and E. Lewis. 2015. The effect of dietary crude protein and phosphorus on grass-fed dairy cow production, nutrient status, and milk heat stability. J. Dairy Sci. 98:517-531.

Sikand, V., P. Tong, and J. Walker. 2010. Heat stability of reconstituted, protein-standardized skim milk powder. J. Dairy Sci. 93:5561-5571.

Singh, H. 2004. Heat stability of milk. Int. J. Dairy Technol. 57:111119.
Sneddon, N. W., N. Lopez-Villalobos, S. R. Davis, R. E. Hickson, L. Shalloo, and D. J. Garrick. 2016. Supply curves for yields of dairy products from first-lactation Holstein Friesian, Jersey and Holstein Friesian-Jersey crossbred cows accounting for seasonality of milk composition and production. Proc. New Zeal. Soc. Anim. Prod. 76:139-143.

Tiezzi, F., D. Pretto, M. De Marchi, M. Penasa, and M. Cassandro. 2013. Heritability and repeatability of milk coagulation properties predicted by mid-infrared spectroscopy during routine data recording, and their relationship with milk yield and quality traits. Animal 7:1592-1599.

Vallas, M., H. Bovenhuis, T. Kaart, K. Pärna, H. Kiiman, and E. Pärna. 2010. Genetic parameters for milk coagulation properties in Estonian Holstein cows. J. Dairy Sci. 93:3789-3796.

Van Slyke, L., and W. Price. 1949. Cheese. Orange Judd Publ. Co. Inc., New York, NY.

VanRaden, P. M., and A. H. Sanders. 2003. Economic merit of crossbred and purebred US dairy cattle. J. Dairy Sci. 86:1036-1044.

Visentin, G., A. McDermott, S. McParland, D. P. Berry, O. A. Kenny, A. Brodkorb, M. A. Fenelon, and M. De Marchi. 2015. Prediction of bovine milk technological traits from mid-infrared spectroscopy analysis in dairy cows. J. Dairy Sci. 98:6620-6629. 